\title{
PERSEPSI GURU TENTANG PELAKSANAAN PENDIDIKAN MULTIKULTURAL DI SEKOLAH DALAM PERSPEKTIF GENDER
}

\author{
Bambang Kariyawan $\mathbf{Y s}^{1}$, Julina ${ }^{2}$ \\ ${ }^{1}$ SMA Cendana Pekanbaru Riau, Indonesia \\ ${ }^{2}$ Universitas Islam Negeri Sultan Syarif Kasim Riau, Indonesia \\ bkariyawan090571@gmail.com \\ julina@uin-suska.ac.id
}

\begin{abstract}
This study aims to determine differences in perceptions of male and female teachers on the implementation of multicultural education in schools. Multicultural education is measured using democratic, bumanistic and pluralistic values. The method used is quantitative descriptive with an instrument in the form of a questionnaire. Descriptive research results found that on average perceptions about the democratic values of male and female teachers were in the range of strongly agree. Perceptions about humanistic education of male and female teachers are also in the range of strongly agree. Meanwhile, perceptions about the pluralistic values of male and female teachers are in the range of agree. Quantitative testing is performed using the Mann-Whitney test. The test results found the Asymp value. Sig. (2-tailed) for each variable of $0.886,0.173$, and 0.481 , greater than $<0.05$ probability value. This means that there are no differences in perceptions about the implementation of multicultural education between male teachers and female teachers.
\end{abstract}

Keywords : Gender Perspective, Multicultural Education, Teacher Perception

\begin{abstract}
ABSTRAK
Penelitian ini bertujuan untuk mengetahui perbedaan persepsi guru laki-laki dan guru perempuan terhadap pelaksanaan pendidikan multikultural di sekolah. Pendidikan multikultural diukur menggunakan nilai demokrasi, humanistik, dan pluralistik. Metode yang digunakan adalah deskriptif kuantitatif dengan instrumen berupa angket. Hasil penelitian deskriptif menemukan bahwa secara rata-rata persepsi tentang nilai demokrasi guru laki-laki dan perempuan berada pada rentang sangat setuju. Persepsi tentang pendidikan humanistik guru laki-laki dan perempuan juga berada pada rentang sangat setuju. Sementara, persepsi tentang nilai pluralistik guru laki-laki dan perempuan berada pada rentang setuju. Pengujian kuantitatif dilakukan menggunakan uji beda Mann-Whitney. Hasil pengujian menemukan nilai Asymp. Sig. (2-tailed) untuk setiap variabel sebesar 0.886, 0.173, dan 0.481 lebih besar dari < nilai probabilitas 0,05. Hal ini berarti bahwa tidak ada perbedaan persepsi tentang pelaksanaan pendidikan multikultural antara guru laki-laki dengan guru perempuan.
\end{abstract}

Kata Kunci: Persepsi Guru, Pendidikan Multikultural, Perspektif Gender 


\section{PENDAHULUAN}

Indonesia termasuk salah satu negara terbesar di dunia yang memiliki kekayaan keragaman sosial budaya (multikultural). Keadaan ini tercermin dari beragamnya suku bangsa, agama, ras, dan budaya. Kondisi keragaman bangsa ini bukanlah kondisi yang baru terbentuk. Kebutuhan untuk menangani pendidikan multikultural sangat signifikan di abad ke-21 karena banyak negara mengalami keragaman sosial dan budaya (Oryan \& Ravid, 2019). Penerapan pendidikan multikultural sangat penting untuk meminimalisasi dan mencegah terjadinya konflik di beberapa daerah. Melalui pendidikan berbasis multikultural, sikap dan mindset (pemikiran) siswa akan lebih terbuka untuk memahami dan menghargai keberagaman. Dalam iklim konservatisme dan kritik yang meningkat saat ini, pendidikan multikultural sama pentingnya dengan sebelumnya. Shannon-Baker (2018) berpendapat perlunya membingkai ulang pendidikan multikultural sebagai praktik yang didasarkan pada prinsip, nilai, yang berorientasi keadilan sosial. Dengan menggunakan penelitian tindakan praktisi, dia mengamatai implementasi praktik pendidikan multikultural di perguruan tinggi. Hasil penelitiannya menemukan bahwa membingkai ulang pendidikan multikultural sebagai praktik di pendidikan tinggi dapat mendorong lebih banyak koalisi di dalam dan di sekolah.

Pendidikan adalah jantung dari tujuan yang ditetapkan oleh komunitas internasional untuk dicapai pada tahun 2030. Salah satu keberagaman yang muncul dan terkadang memibulkan konflik adalah ketimpangan dari sisi gender. Inilah sebabnya mengapa UNESCO memprioritaskan kesetaraan gender di dalam dan melalui pendidikan. Taruhannya ada dua: pendidikan anak perempuan dan perempuan adalah hak asasi manusia yang mendasar, dan juga merupakan faktor penting untuk perdamaian dan pembangunan berkelanjutan. Mencapai kesetaraan gender dalam partisipasi pendidikan, dalam proses belajar mengajar dan dalam akses ke peluang sosial dan ekonomi yang dapat difasilitasi oleh pendidikan adalah ambisi utama yang saling terkait dalam dua tujuan Pembangunan Berkelanjutan (Sustainable Development Goals atau SDGs). SDGs 2030 memiliki 17 tujuan dimana tujuan ke empat adalah tentang pendidikan dan tujuan ke lima tentang kesetaraan gender (UNESCO, 2019). Tujuan-tujuan ini juga merupakan kunci Kerangka Aksi Pendidikan 2030, yang menyerukan kepada negara-negara untuk mengadopsi strategi yang tidak hanya mencakup akses ke pendidikan untuk semua tetapi juga menangani masalah kesetaraan gender yang substantif: mendukung kebijakan, perencanaan dan lingkungan belajar yang peka gender; mengarusutamakan masalah gender dalam pelatihan dan kurikulum guru; dan menghilangkan diskriminasi dan kekerasan berbasis gender di sekolah. 
Vol. 19, No. 1, 2020, Hal. 26-49

Namun kenyataan di lapangan konsep pendidikan multikultural masih belum dipahami secara utuh, sehingga diperlukan penjelasan lebih detil tentang indikator-indikator pendidikan multikultural serta persepsi dari guru sebagai pelaksana di lapangan. Penting bagi para guru untuk belajar lebih banyak tentang berbagai pendekatan pendidikan multikultural. Penelitian ini memiliki dua tujuan yaitu pertama untuk menganalisis persepsi guru terhadap nilai demokrasi, humanistik, dan pluralistik pada pendidikan multikultural di Kota Pekanbaru. Selain itu, penelitian ini juga ingin menguji apakah terdapat perbedaan persepsi guru berdasarkan gender dalam pelaksanaan pendidikan multikultural. Penelitian ini penting dilakukan mengingat keberhasilan guru dalam mengajarkan pendidikan multikultural akan menghasilkan siswa yang lebih toleran terhadap perbedaan dan pada akhirnya akan berdampak pada kerukunan hidup bermasyarakat.

Pendidikan multikultural adalah konsep yang telah dikembangkan untuk menghilangkan kesulitan dan ketidaksetaraan yang dialami karena perbedaan budaya dengan pada dasarnya memungkinkan siswa untuk mengambil keuntungan dari peluang dan kemungkinan yang sama dalam lingkungan yang demokratis. Karena fakta bahwa masalah budaya dari setiap masyarakat dan berbeda dan beragam, ada sejumlah deskripsi mengenai multikulturalisme. Pendidikan multikultural adalah proses yang mengharuskan penciptaan lembaga pendidikan yang baik dalam struktur dan membentuk jaminan bahwa siswa dapat memperoleh peluang dan keberhasilan akademik yang sama. Pendidikan multikultural menekankan perlunya menciptakan masyarakat di mana hak-hak universal dan demokratis berada di garis depan dan rasa hormat ditunjukkan terhadap berbagai budaya yang ada dalam masyarakat tersebut (Alanay \& Aydin, 2016).

Pendidikan multikultural adalah pendekatan untuk pengajaran dan pembelajaran yang didasarkan pada nilai-nilai demokrasi yang menegaskan pluralisme budaya dalam masyarakat yang beragam secara budaya di dunia yang saling bergantung. Saat ini ada dua sudut pandang atau perspektif pendidikan multikultural di Amerika Serikat, yaitu perspektif asimilasi atau "melting-pot" dan perspektif pluralisme atau "global". Perspektif asimilasi dari pendidikan multikultural adalah bahwa mikrokultur harus melepaskan budaya dan identitas asli mereka untuk berbaur atau terserap ke dalam budaya Anglo-Barat yang dominan di Eropa. Perspektif global adalah bahwa mikrokultur dapat mempertahankan banyak tradisi mereka seperti bahasa, agama, dan adat istiadat sosial sambil mengadopsi banyak aspek budaya Anglo-Barat yang dominan (Ameny-Dickson, 2004).

Menurut Tilaar (2004) dalam pendidikan multikultural terkandung nilai-nilai demokrasi, humanistik, dan pluralistik yang dapat meningkatkan sikap menghargai akan keragaman budaya di masyarakat. Urgensinya untuk mencegah terjadinya berbagai konflik di beberapa daerah dan siswa 
Vol. 19, No. 1, 2020, Hal. 26-49

menjadi lebih terbuka dalam menghargai keragaman.Prinsip-prinsip pendidikan multikultural yang disampaikan oleh Tilaar menggambarkan arah dari pendidikan multikultural, yaitu menciptakan manusia yang terbuka terhadap perkembangan zaman dan keragaman beberapa aspek dalam kehidupan modern.

Nilai pertama dari pendidikan multicultural adalah nilai demokrasi. Marri (2010) menulis artikel tentang demokrasi multikultural dengan tujuan untuk memberikan kontribusi tentang persimpangan antara pendidikan demokratis dan multikultural. Tujuan yang lebih besar dari persimpangan ini adalah untuk meningkatkan praktik guru guna memenuhi kebutuhan siswa dengan lebih baik atau mereka yang paling tidak puas di sekolah. Siswa-siswa ini tidak berpartisipasi aktif karena mereka merasa dikecualikan oleh perbedaan berdasarkan faktor sosial-ekonomi, bahasa, dan budaya. Mengajar tentang demokrasi dan untuk demokrasi multikultural dapat menawarkan kesempatan bagi guru untuk mengubah praktik mereka dengan memasukkan perbedaan sosial-ekonomi, budaya, dan politik dari semua siswa mereka.

Nilai kedua dari pendidikan multikultural adalah nilai humanistik. Teori humanistik, yang berarti memanusiakan manusia adalah salah satu teori yang dapat melandasi pembentukan kepekaan sosial. Dalam penelitiannya, Alifah (2018) menemukan bahwa metode kolaboratif dari pendidikan multikultural dan teori humanistik ketika pembelajaran di kelas lebih efektif untuk meningkatkan sensitivitas sosial bagi siswa sekolah dasar. Selain itu, Kariyawan (2015) menemukan bahwa dengan pembentukan kelompok kerja siswa dari kondisi sosiometri yang beragam dapat meredam perilaku berkonflik siswa dengan menerima perbedaan dalam kelompok kerja mereka. Belajar menerima keberadaan orang yang berbeda akan membuat proses hidup bermasyarakat menjadi lebih dinamis. Penelitian lain dikemukakan oleh Rockwell, Vidmar, Harvey, \& Greenwood (2019) yang menyatakan bahwa mendorong siswa untuk memiliki empati merupakan sasaran umum dalam pembelajaran. Mereka menemuka bahwa siswa yang mengikuti mata pelajaran sosiologi memiliki perubahan positif dalam hal empati dibandingkan yang tidak mengikuti mata pelajaran sosiologi.

Selanjutnya, nilai ketiga adalah nilai pluralistik. Nilai ini mengacu pada adanya beragam kepentingan dan bersaing sebagai dasar untuk keseimbangan demokratis, yang sangat penting untuk mendapatkan tujuan oleh individu. Dalam budaya pluralis, kelompok-kelompok unik tidak hanya hidup berdampingan, tetapi juga menganggap kualitas kelompok lain sebagai sifat yang pantas dimiliki dalam budaya dominan. Lebih jauh, dalam lingkungan sosial pluralistik, harapan integrasi yang kuat terjadi antara kelompok mayoritas dan minoritas dari pada harapan asimilasi. Faktanya, asimilasi mengarah pada pengabaian perbedaan dan nilai-nilai kelompok minoritas dan untuk memaksakan 
Vol. 19, No. 1, 2020, Hal. 26-49 hegemoni budaya oleh kelompok dominan. Pluralisme adalah kekuatan fungsional vital dalam masyarakat, meskipun tidak didukung dan dianut dalam kebijakan dan praktik kelembagaan (misalnya, dalam otoritas perumahan, distrik sekolah, dan pemerintah kota) dan dalam kebiasaan masyarakat (Colombo, 2012).

Selain ketiga nilai tersebut, Blum (2014) meyatakan ada tiga nilai dalam pendidikan multikultural yaitu mengakui perbedaan, kohesi nasional, dan kesetaraan. Tujuan pendidikan bagi masyarakat yang terdiri dari berbagai kelompok etnis, budaya, dan ras harus melibatkan tiga nilai berbeda — mengakui perbedaan, kohesi nasional, dan kesetaraan. Pengakuan perbedaan mengakui dan menghormati identitas etnokultural dan dalam konteks pendidikan juga mendorong keterlibatan timbal balik di seluruh perbedaan. Kohesi nasional melibatkan pengajaran rasa keterikatan warga pada suatu negara dan sesama warga negara dari berbagai kelompok dan identitas. Sementara kesetaraan adalah ide yang kompleks yang melibatkan perlakuan yang sama oleh guru siswa dari kelompok yang berbeda, dan juga hasil siswa yang relatif sama di antara kelompok yang berbeda. Dia berpendapat bahwa pengakuan perbedaan, kohesi nasional, dan kesetaraan adalah tiga nilai berbeda, yang pantas mendapat tempat sentral dalam tujuan pendidikan dari program pendidikan masyarakat yang majemuk secara etnokultural dan rasial. Mempromosikan salah satu dari nilai-nilai tersebut tidak menjamin promosi salah satu dari nilai yang lain, sehingga ketiganya harus ditangani secara eksplisit; namun, dalam beberapa kasus praktik tertentu dapat mempromosikan lebih dari satu, seperti kasus menghormati dialek bahasa dirumah siswa (karena mempromosikan nilai pengakuan perbedaan dan nilai kesetaraan).Juga, harus diingat bahwa masing-masing dari ketiganya tidak menyebutkan nilai tunggal tetapi sekumpulan nilai; dan dalam kasus kesetaraan bahwa keluarga sangat kompleks dan beragam.

Mempelajari persepsi guru merupakan hal yang penting karena persepsi akan sangat erat kaitannya dengan harapan. Persepsi guru didefinisikan sebagai kepercayaan guru terhadap sesuatu. Hal ini bisa dikaitkan kepada kepercayaan guru terhadap prestasi siswa, perilaku sosial siswa, atau tingkat kemampuan siswa. Sementara itu, kesan dari seorang guru sering dapat memprediksi perilaku dan prestasi dimasa yang akan datang. Persepsi dan kesan guru dapat berasal dari berbagai sumber termasuk ras, jenis kelamin, dan status sosial (Dusek, 1985 dalam Rong, 1996). Hasil penelitian Mpofu, Thomas \& Chan (2004) konsisten dengan yang ada pada sejumlah studi sebelumnya di negara-negara Barat di mana kelompok minoritas berisiko menerima penerimaan sosial yang lebih rendah di sekolah. Temuan ini cukup menarik secara teoritis dan praktis, terutama karena adanya efek 
yang berpotensi mengacaukan dari sisi perbedaan dalam etnis guru, jenis kelamin guru, prestasi sekolah, dan proporsi ras di kelas.

Penelitian mengenai pengaruh gender terhadap persepsi guru telah banyak dilakukan dan menyimpulkan hasil yang beragam. Dari sisi siswa, beberapa peneliti menemukan tidak ada pengaruh gender siswa terhadap persepsi guru, sementara peneliti lain menemukan bahwa gender siswa berpengaruh terhadap harapan guru. Dusek dan Joseph (1983) dalam Rong (1996) melakukan meta analisis terhadap 20 artikel dan menemukan bahwa harapan sebagai fungsi dari gender siswa tidak terkait dengan pengukuran akademis, namun terkait dengan pengembangan kepribadian atau sosial. Perkembangan penelitian selanjutnya tidak hanya meneliti gender siswa, namun mulai dikombinasikan dengan gender guru juga.

Hasil penelitian Rong (1996) menemukan bahwa guru laki-laki dan perempuan memiliki persepsi yang berbeda terhadap peran siswa. Hasil analisisnya menemukan bahwa ras dan gender mempengaruhi persepsi guru, namun besaran dan arah pengaruh tersebut juga dipengaruhi oleh ras guru. Siswa perempuan sering diberikan nilai lebih tinggi dibandingkan siswa laki-laki oleh para guru (tanpa memperdulikan ras dan gender guru). Guru perempuan yang berkulit hitam menilai skor perilaku sosial siswa perempuan lebih tinggi dari siswa laki-laki. Gender siswa juga menunjukkan hubungan yang kuat dengan skor nilai guru diantara guru perempuan berkulit putih. Selain menunjukkan pola yang sama pada pengaruh gender siswa, pengaruh ras siswa terhadap persepsi guru menunjukkan adanya perbedaan antara guru perempuan berkulit hitam dan putih. Diantara siswasiswa yang dinilai oleh guru perempuan berkulit hitam, ras tidak menunjukkan pengaruh yang signifikan terhadap persepsi guru pada skor total perilaku sosial. Perbedaan nilai rata-rata antara siswa berkulit putih dan hitam sangat kecil dan tidak signifikan. Namun terdapat pengaruh yang signifikan antara ras siswa dengan skor nilai dari guru perempuan berkulit putih. Siswa berkulit hitam dinilai lebih rendah dibanding siswa berkulit puth pada skor total perilaku sosial. Lebih lanjut hasil penelitiannya menemukan efek kombinasi yang relatif kompleks antara ras dan gender siswa dengan ras guru. Meskipun tidak terdapat perbedaan skor perilaku sosial yang signifikan pada siswa perempuan dari guru perempuan kulit hitam dan putih, namun pengaruh ras guru dan siswa muncul ketika guru perempuan menilai siswa laki-laki. Perbedaan skor perilaku sosial siswa antara guru lakilaki dan perempuan menyatakan adanya kemungkinan persepsi guru perempuan mengenai perilaku sosial yang dapat diterima memiliki parameter yang berbeda dengan guru laki-laki.

Penelitian lain seperti Motta dan Vane (1976) dan Simmons (1980) menguji persepsi guru terhadap peran gender siswa. Siswa perempuan sering dipersepsikan lebih lebih mandiri, empati, 
Vol. 19, No. 1, 2020, Hal. 26-49 berorientasi prestasi sementara siswa laki-laki lebih agresif dan bebas. Perbedaan antara nilai guru lakilaki dan perempuan cenderung terjadi pada kategori kemampuan, kepribadian, dan perilaku seperti "kreatif”. "keras kepala", dan "dengan sopan meminta tolong”. Barangkali guru laki-laki mempersepsikan kualitas pada siswa laki-laki lebih positif dibandingkan guru perempuan. Selanjutnya, Waight (2007) mengeksplorasi bagaimana persepsi guru terhadap pendidikan multikultural mempengaruhi cara mereka mengajar. Hasil wawancaranya, menemukan bukti bahwa pendidikan multikultural sering dilakukan atas dasar sesuai kebutuhan. Terkait dengan upaya meminimalisir stereotype antar gender, Kariyawan (2015) melakukan Penelitian Tindaka Kelas (PTK) dan menemukan bahwa setelah beberapa siklus, terdapat peningkatan kemampuan siswa dalam mendengarkan pendapat lawan gender dan kemampuan merespon positif terhadap lawan gender. Selanjutnya Diniaty (2016) melakukan penelitian mengenai perilaku siswa yang mengganggu (PSM) di SMK Kehutanan Pekanbaru. Hasil penelitiannya menemukan guru perempuan menilai bentuk PSM lebih tinggi dibandingkan dengan guru laki-laki. Guru perempuan ternyata lebih merasakan adanya PSM terjadi di kelas dibandingkan dengan guru laki-laki. Namun perbedaan ini tidak signifikan.

\section{METODE}

Jenis penelitian ini adalah penelitian deskriptif kuantitatif. Analisis deskriptif dilakukan untuk memberikan gambaran terhadap objek atau subjek yang diteliti melalui data sampel atau populasi sebagaimana adanya, tanpa melakukan analisis dan membuat kesimpulan yang berlaku umum. Sementara, untuk mengetahui apakah ada perbedaan persepsi antara laki-laki dan perempuan digunakan uji beda Mann-Whitney. Instrumen penelitian yang digunakan adalah angket dengan menggunakan aplikasi google form. Teknik pengambilan sampel yang digunakan adalah convenience sampling yaitu pengambilan sampel berdasarkan kemudahan untuk mendapatkannya. Sebanyak 54 orang guru dari berbagai sekolah berpartisipasi dalam penelitian. Angket disusun dengan memperhatikan indikator dari variabel tentang pendidikan multikultural yang meliputi indikator nilainilai demokrasi, humanistik, dan pluralistik. Indikator nilai-nilai demokrasi terdiri dari membangun hak asasi manusia, membangun sikap anti diskriminasi, memberi kebebasan berpendapat dan berkreatifitas, menghargai perbedaan kemampuan. Selanjutnya, indikator nilai-nilai humanistik terdiri dari membangun toleransi, membangun kasih sayang. Terakhir adalah indikator nilai-nilai pluralistik terdiri dari menghargai keragaman bahasa, menghargai keragaman agama, membangun sikap sensitif gender, membangun pemahaman kritis terhadap ketidakadilan dan perbedaan status, menghargai perbedaan umur. 


\section{HASIL DAN PEMBAHASAN}

Kondisi demografi responden yang berpartisipasi dalam penelitian ini dapat dilihat pada Tabel 1. Berdasarkan dari 54 responden terlihat bahwa mayoritas responden dalam pnlt ini berada pada rentang usia antara 41 sampai dengan 50 tahun. Jenjang pendidikan responden adalah pendidikan S1, memiliki suku Minang, dan beragama Islam. Sharma (2005) menyatakan bahwa guru membutuhkan persiapan yang efektif dalam pendidikan multikultural untuk menghadapi siswa yang berbeda budaya. 
Tabel 1.Profil Demografi Responden

\begin{tabular}{|c|c|c|c|c|}
\hline \multirow[t]{2}{*}{ Demografi Responden } & & \multicolumn{2}{|c|}{ JenisKelamin } & \multirow[t]{2}{*}{ Jumlah } \\
\hline & & Laki-Laki & Perempuan & \\
\hline \multirow[t]{5}{*}{ Umur } & $25-30$ & 6 & 5 & 11 \\
\hline & $31-40$ & 10 & 6 & 16 \\
\hline & $41-50$ & 9 & 13 & 22 \\
\hline & $>50$ & 2 & 3 & 5 \\
\hline & Jumlah & 27 & 27 & 54 \\
\hline \multirow[t]{6}{*}{ Tingkat Pendidikan } & S1 & 22 & 25 & 47 \\
\hline & $\mathrm{S} 2$ & 5 & 2 & 7 \\
\hline & Jumlah & 27 & 27 & 54 \\
\hline & Banjar & 1 & 0 & 1 \\
\hline & Batak & 3 & 1 & 4 \\
\hline & Jawa & 8 & 7 & 15 \\
\hline \multirow{4}{*}{ Suku } & Melayu & 5 & 6 & 11 \\
\hline & Minang & 10 & 13 & 23 \\
\hline & Jumlah & 27 & 27 & 54 \\
\hline & Islam & 26 & 26 & 54 \\
\hline \multirow{2}{*}{ Agama } & Protestan & 1 & 1 & 2 \\
\hline & Jumlah & 27 & 27 & 54 \\
\hline
\end{tabular}

\section{Persepsi Guru tentang Nilai-nilai Demokrasi}

Gambar 1 dan 2 menampilkan jawaban responden laki-laki dan perempuan terkait dengan pernyataan pada indikator pendidikan demokrasi. Rata-rata jawaban untuk keseluruhan indikator dapat dilihat pada Gambar 2. Tidak terdapat perbedaan yang mencolok antara guru laki-laki dan perempuan. Secara rata-rata dari keseluruhan indikator, $81 \%$ guru laki-laki dan $80 \%$ guru perempuan menjawab sangat setuju, dan persentase yang sama yaitu 16\% menjawab setuju. Secara keseluruhan, jawaban responden untuk nilai demokrasi ini berada pada rentang sangat setuju yang artinya para guru sangat setuju pada pernyataan-pernyataan terkait dengan nilai demokrasi.

Berdasarkan jawaban per indikator, persentase jawaban tertinggi yaitu 100\% guru baik laki-laki atau perempuan menyatakan sangat setuju untuk pernyataan "Setiap anak mempunyai hak memperoleh pendidikan untuk masa depannya”.Untuk responden guru laki-laki, pernyataan lain juga mendapat respon sangat setuju 100\% adalah pada pernyataan "Setiap siswa mempunyai tingkat 
Vol. 19, No. 1, 2020, Hal. 26-49 martabat dan kedudukan yang sama sebagai makhluk ciptaan Tuhan. Sebaliknya, persentase jawaban sangat setuju terendah pada guru laki-laki yaitu 44.4\% berada pada pernyataan "Siswa berhak untuk berpendapat dalam segala aspek di sekolah". Pada guru perempuan, persentase jawaban sangat setuju terendah yaitu 55.6\% adalah untuk pernyataan "Siswa diberi kebebasan memberikan kritik atau saran untuk kemajuan sekolah".

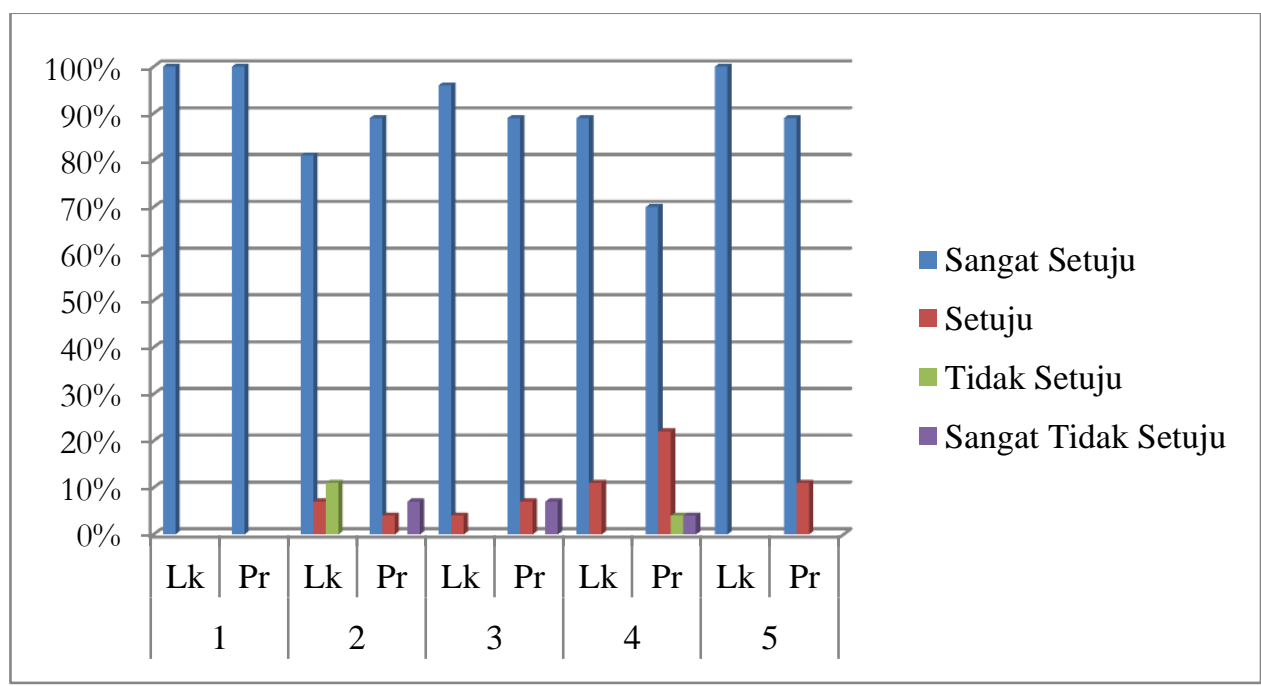

Gambar1.

Pemahaman Demokrasi Guru Laki-laki dan Guru Perempuan untuk Pernyataan 1-5

Pada Gambar 1 dapat dijelaskan juga bahwa untuk pernyataan nomor satu tentang "Setiap anak mempunyai hak memperoleh pendidikan untuk masa depannya" guru laki-laki dan guru perempuan memilih jawaban yang sama sangat setuju 100\%. Hal ini sesuai dengan Pasal 31 ayat (1) UUD 1945 menyatakan bahwa "Setiap warga negara berhak mendapat pendidikan." Selain itu, tujuan ke empat SDGs adalah juga menjamin kualitas pendidikan yang inklusif dan merata serta meningkatkan kesempatan belajar sepanjang hayat untuk semua (sdgsindonesia.or.id)

Pada pernyataan nomor dua tentang "Setiap anak mempunyai hak pribadi yaitu hak untuk memeluk agama dan beribadah menurut agama masing-masing" persentase jawaban sangat setuju guru perempuan lebih tinggi dari pada guru laki-laki (yaitu 89\% vs 81\%). Masih ada 7\% guru perempuan dan 11\% guru laki-laki yang menjawab sangat tidak setuju untuk pernyataan ini. Sejalan Pasal 29 UUD 1945 ayat (2) disebutkan "Negara menjamin kemerdekaan tiap-tiap penduduk untuk memeluk agamanya masing-masing dan untuk beribadat menurut agamanya dan kepercayaannya itu." 
Vol. 19, No. 1, 2020, Hal. 26-49

Pada pernyataan nomor tiga tentang "Setiap siswa mempunyai hak sama untuk mendapatkan pengayoman dan perlakuan yang sama di sekolah" persentase guru laki-laki yang menjawab sangat setuju sebanyak 96\% dimana hal ini lebih tinggi dari persentase guru perempuan yang menjawab sangat setuju yaitu sebanyak $89 \%$. Salah satu targer dari pendidikan berkualitas yang dicanangkan dalam SDGs adalah pada tahun 2030, menjamin semua peserta didik memperoleh pengetahuan dan keterampilan yang diperlukan untuk meningkatkan pembangunan berkelanjutan, termasuk antara lain, melalui pendidikan untuk pembangunan berkelanjutan dan gaya hidup yang berkelanjutan, hak asasi manusia, kesetaraan gender, promosi budaya damai dan non kekerasan, kewarganegaraan global dan penghargaan terhadap keanekaragaman budaya dan kontribusi budaya terhadap pembangunan berkelanjutan (sdgsindonesia.or.id).

Pada pernyataan nomor empat tentang "Pelayanan pendidikan diberikan sama pada semua orang tua tanpa melihat kontribusi yang diberikan" guru laki-laki yang menjawab sangat setuju lebih tinggi dari guru perempuan (89\% vs 70\%). Selanjutnya, untuk pernyataan nomor lima tentang "Setiap siswa mempunyai tingkat martabat dan kedudukan yang sama sebagai makhluk ciptaan Tuhan”, guru laki-laki menjawab 100\% sangat setuju sementara hanya 89\% guru perempuan yang sangat setuju. Menurut Pancasila dan UUD Tahun 1945, seluruh hak dan martabat yang dimiliki oleh manusia itu harus dilindungi, dijaga dan diberikan hak pengakuannya secara utuh, tanpa dikurangi sedikitpun, agar dirinya dapat hidup dengan aman dan mendapatkan kesejahteraan lahir dan batin.

Indikator selanjutnya yaitu nomor enam sampai dengan Sembilan dapat dilihat pada Gambar 2. Berdasarkan data pada Gambar 2 untuk pernyataan nomor enam tentang "Siswa berhak untuk berpendapat dalam segala aspek di sekolah" terlihat bahwa sebanyak 67\% guru perempuan menjawab sangat setuju smentara guru laki-laki hanya 44\%. Demokrasi dalam pendidikan menggunakan prinsip equal opportunity for all. Artinya, anak didik mendapat peluang, kesempatan, dan perlakuan yang sama. 


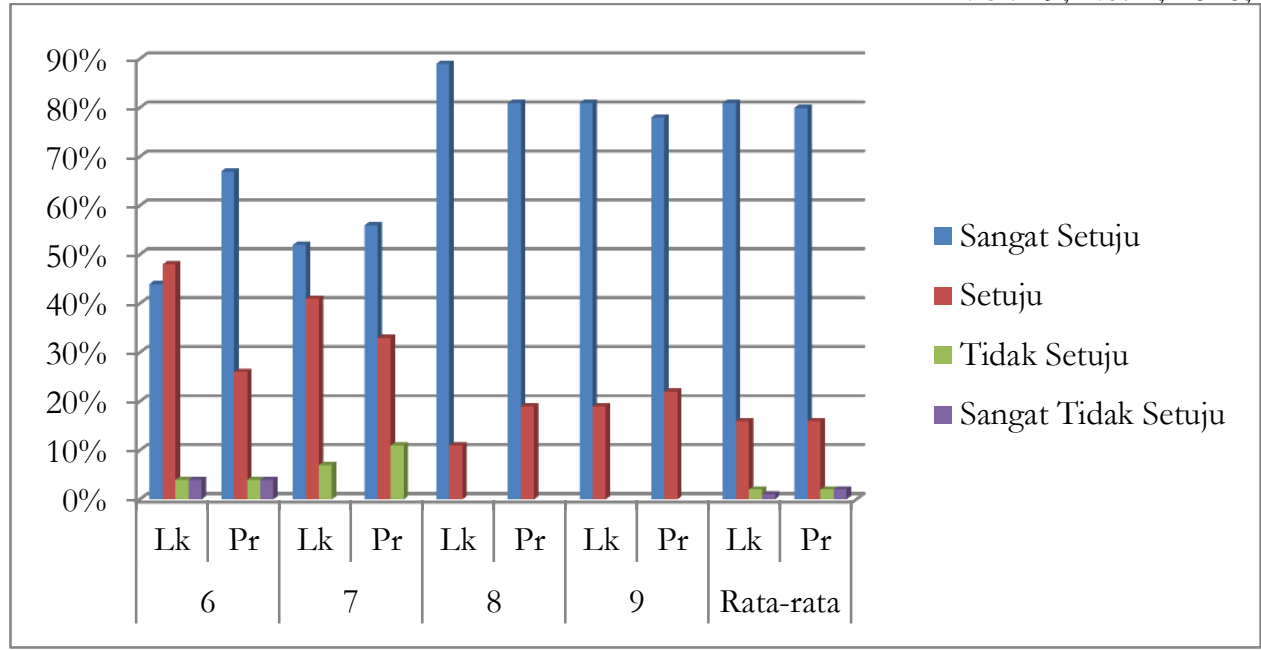

Gambar 2

Pemahaman Demokrasi Guru Laki-laki dan Guru Perempuan untuk Pernyataan 6-9

Senada dengan pernyataan nomor enam, pernyataan nomor tujuh menanyakan persepsi guru tentang "Siswa diberi kebebasan memberikan kritik atau saran untuk kemajuan sekolah". Respon dari guru perempuan yang menjawab sangat setuju sebanyak 56\% sementara hanya 52\% guru laki-laki menjawab sangat setuju. Guru biasanya memiliki perasaan campur aduk ketika siswa diminta untuk memberikan kritik dan saran. Lagi pula, tidak dapat dihindari bahwa beberapa siswa mungkin menggunakan kesempatan untuk memberikan kritik dan saran. Sebagian besar kritik dan saran siswa dapat benar-benar bermanfaat, menawarkan guru kesempatan untuk kesadaran diri dan wawasan yang dapat membantu pekerjaan guru menjadi lebih baik di kemudian hari. Kritik dan saran juga baik untuk siswa, karena membantu mereka merasa lebih terlibat penuh dalam pendidikan mereka. Kritik dan saran memberikan saran nyata kepada guru tentang membuat proses pendidikan lebih menyenangkan dan efektif. Guru yang lebih responsif terhadap siswa mereka memiliki peluang lebih baik untuk memberikan pengalaman pendidikan yang berkualitas.

Pernyataan nomor delapan tentang "Setiap anak mempunyai daya kreativitas sesuai dengan bakat yang dimiliknya" menunjukkan bahwa guru laki-laki dan guru perempuan sama-sama menjawab sangat setuju 81\%. Menurut Ameny-Dixon (2004) pendidikan multikultural akan meningkatkan keahlian pemecahan masalah secara kreatif melalui perbedaan perspektif yang diaplikasikan untuk masalah yang sama untuk mencapai solusi.

Item terakhir yaitu pernyataan nomor sembilan tentang "Perbedaan siswa dalam mengekspresikan sikap atau pendapat harus dihargai" mendapat respon sangat setuju sebanyak 81\% dari guru laki-laki dan 78\% dari guru perempuan. Sikap atau karakter toleransi merupakan salah satu 
Vol. 19, No. 1, 2020, Hal. 26-49

diantara 18 karakter yang saat ini dikembangkan oleh para ahli pendidikan. Pendidikan multikultural meningkatkan hubungan positif melalui pencapaian tujuan bersama, saling menghargai, saling mengapresiasi, dan komitmen untuk kesetaraan.

\section{Persepsi Guru tentang Nilai Humanistik}

Analisis jawaban guru untuk pendidikan humanistik dapat dilihat pada Gambar 3. Pada guru laki-laki, rata-rata yang menjawab sangat setuju sebanyak 59\% sedangkan guru perempuan sebanyak 54\%. Selanjutnya, untuk jawaban setuju, guru laki-laki sebanyak 35\% dan guru perempuan sebanyak $33 \%$. Secara keseluruhan, jawaban responden untuk nilai humanistik ini berada pada rentang sangat setuju yang artinya para guru sangat setuju pada pernyataan-pernyataan terkait dengan nilai humanistik. Analisis jawaban per item indikator menunjukkan bahwa pada guru laki-laki, persentase jawaban sangat setuju tertinggi $(74.1 \%)$ adalah untuk pernyataan "Kasih sayang perlu dikembangkan dan ditanamkan agar menyatu pada setiap siswa dalam kehidupan sehari-hari." Pada guru perempuan, pernyataan ini juga mendapat respon sangat setuju tertinggi dengan persentase sebesar 85\%. Sebaliknya, jawaban sangat setuju terendah pada guru laki-laki (29.6\%) adalah berada pada pernyataan ke 12 yaitu: "Paham chawinisme (cinta tanah air yang berlebih) perlu ditanamkan untuk membina nasionalisme siswa." Hal ini menunjukkan pola yang sama dimana respon jawaban sangat setuju terendah pada guru perempuan (7.4\%) juga berada pada pernyataan ini. Untuk lebih rinci dapat dijelaskan pada Gambar 3.

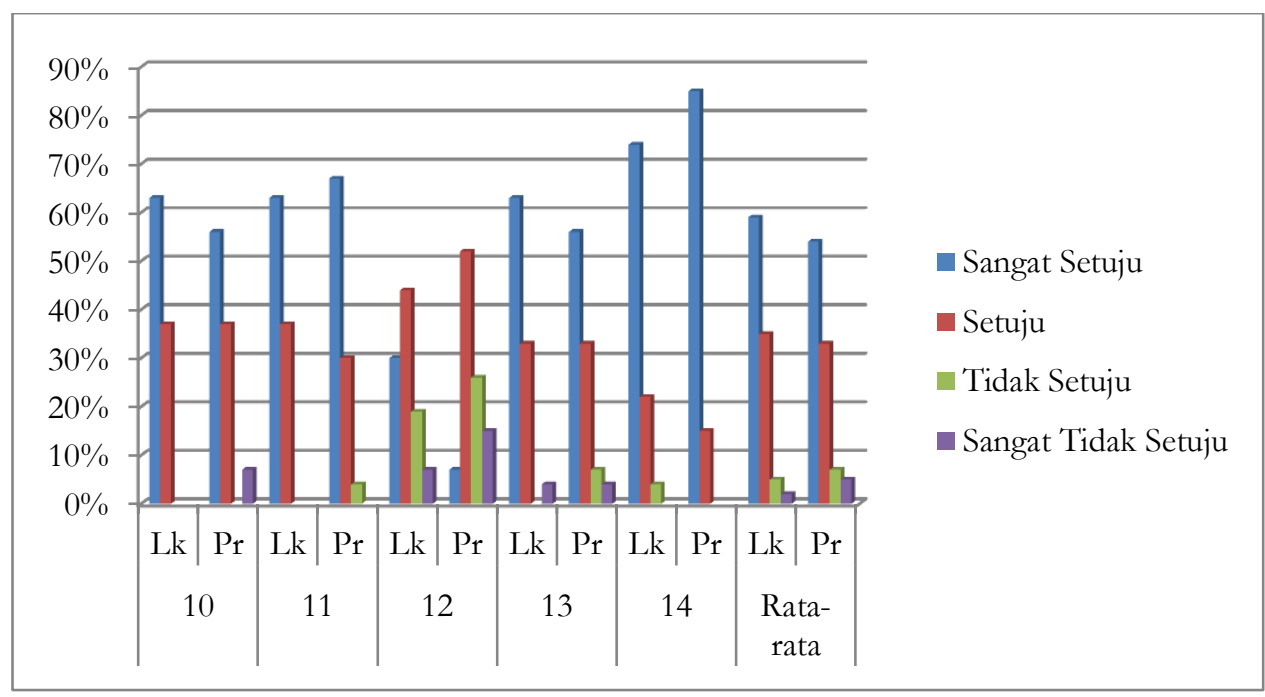

Gambar 3

Pemahaman Humanistik Guru Laki-laki dan Guru Perempuan untuk Pernyataan 10-14 
Pernyataan nomor 10 tentang "Perbedaan perlu dipahami sebagai kekayaan" mendapat respon sangat setuju dari guru laki-laki sebanyak 63\% dari guru perempuan sebanyak 56\%. Pendidikan multikultural meningkatkan produktivitas karena berbagai sumber daya mental tersedia untuk menyelesaikan tugas-tugas yang sama. Pendidikan multikultural juga meningkatkan pertumbuhan kognitif dan moral diantara semua orang (Ameny-Dixon, 2004).

Pernyataan nomor 11 tentang "Prinsip Bhinneka Tunggal Ika dapat menggambarkan keragaman dari masyarakat Indonesia" bergantian guru perempuan memiliki persentase jawaban sangat setuju lebih banyak yaitu 67\% sementara 63\% guru laki-laki. Menurut Ameny-Dixon (2004) salah satu manfaat jangka panjang pendidikan multikultural adalah memperbaharui vitalitas masyarakat melalui kekayaan budaya yang berbeda dari seluruh masyarakat dan mendorong pengembangan sudut pandang dunia yang lebih luas dan kompleks

Pernyataan nomor 12 tentang "Paham chauvinisme (cinta tanah air yang berlebih) perlu ditanamkan untuk membina nasionalisme siswa" mendapat respon sangat setuju dari guru laki-laki sebanyak 30\% guru laki-laki dan hanya 7\% guru perempuan menjawab sangat setuju. Sebaliknya terdapat 26\% guru laki-laki dan 41\% guru perempuan menjawab tidak setuju dan sangat tidak setuju. Chauvinisme adalah produk yang hampir alami dari konsep nasional sejauh ia muncul langsung dari ide lama tentang misi nasional. Selama konsep ini tidak berkembang menjadi ideologi chawinisme dan tetap berada di ranah kebanggaan nasional atau bahkan kebangsaan, sering kali timbul rasa tanggung jawab yang tinggi terhadap kesejahteraan orang-orang yang masih terbelakang.

Pernyataan nomor 13 tentang "Kasih sayang perlu diungkapkan bagi semua siswa tanpa memandang latar belakang keluarga" mendapat respon sangat setuju sebanyak 63\% dari guru laki-laki dan 56\% dari guru perempuan. Keluarga adalah sekolah pertama kebajikan, dalam keluarga kita belajar tentang cinta, komitmen, pengorbanan, dan meyakini sesuatu yang lebih besar daripada diri kita sendiri. Keluarga adalah peletak dasar pendidikan moral. Selanjutnya, masih terkait dengan kasih saying, pernyataan nomor 14 tentang "Kasih sayang perlu dikembangkan dan ditanamkan agar menyatu pada setiap siswa dalam kehidupan sehari-hari” direspon guru perempuan dengan jawaban sangat setuju sebanyak 85\% dan guru laki-laki sebanyak 74\%. Dalam jangka panjang, pendidikan multikultural dapat menurunkan stereotipe dan prasangka melalui kontak dan interaksi langsung antar individu-individu yang berbeda.

\section{Persepsi Guru tentang Nilai Pluralistik}


Vol. 19, No. 1, 2020, Hal. 26-49

Terdapat delapan item yang digunakan untuk mengukur persepsi guru tentang nilai pluralistik. Rata-rata jawaban sangat setuju pada guru laki-laki sebanyak 35\%, sedangkan pada guru perempuan sebanyak 44\%. Selanjutnya, rata-rata yang menjawab setuju sebanyak 33\% untuk guru laki-laki dan 31\% untuk guru perempuan (lihat pada Gambar 5). Secara keseluruhan, jawaban responden untuk nilai pluralistik ini berada pada rentang setuju yang artinya para guru setuju pada pernyataanpernyataan terkait dengan nilai pluralistik.

Analisis jawaban per item indikator menunjukkan bahwa persentase jawaban sangat setuju tertinggi (93\% pada guru laki-laki dan 96\% pada guru perempuan) berada pada pernyataan: "Hubungan antara manusia dengan Tuhan Yang Maha Esa merupakan hak pribadi yang paling hakiki”.Kondisi sebaliknya yaitu jawaban sangat setuju terendah yaitu hanya 4\% untuk pernyataan "Batasan umur siswa tidak perlu diberlakukan di sekolah agar tercipta keragaman umur". Pada guru perempuan, bahkan tidak ada satupun yang menyatakan sangat setuju untuk pernyataan ini. Namun demikian, terdapat 26\% guru laki-laki dan 22\% guru perempuan yang menyatakan setuju untuk pernyataan ini. Untuk lebih rinci, jawaban responden dapat dilihat pada Gambar 4 dan 5.

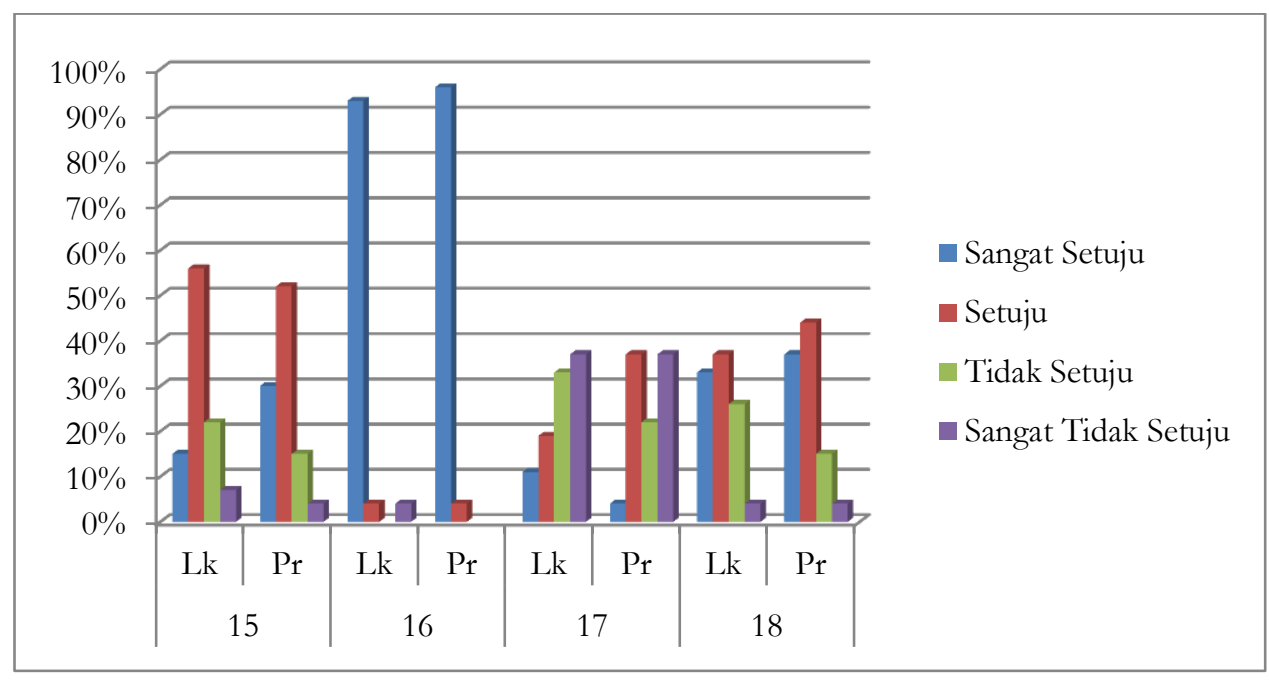

Gambar 4

Pemahaman Pluralistik Guru Laki-laki dan Guru Perempuan untuk Pernyataan 15-18

Pernyataan nomor 15 tentang "Pada kesempatan forum non formal siswa dapat menggunakan bahasa yang dipakai sehari-hari untuk menyampaikan pendapat", sebanyak 30\% guru perempuan merespon sangat setuju dibanding hanya setengahnya yaitu 15\% dari guru laki-laki. Namun 19\% guru perempuan memilih tidak setuju dan sangat tidak setuju sedang guru laki-laki memilih jawaban tersebut sebanyak 29\%. Berkaitan dengan upaya pembinaan bahasa, Pembicaraan di kelas sering kali 
Vol. 19, No. 1, 2020, Hal. 26-49

terbatas dan digunakan untuk menguji pemahaman daripada mengembangkan pemikiran. Banyak peneliti telah menemukan bahwa guru mendominasi pembicaraan kelas. Selain banyaknya pembicaraan guru di kelas, para peneliti telah mengidentifikasi jenis-jenis pembicaraan yang semakin membantu. Sebagai contoh, penelitian seminal Durkin (1978/1979) tentang instruksi pemahaman menegaskan bahwa guru terutama mengandalkan pertanyaan untuk memeriksa pemahaman. Tanya jawab adalah alat penting yang dimiliki guru, tetapi siswa juga perlu kesempatan untuk berdialog jika ingin belajar. Dan, sayangnya, sebagian besar pertanyaan menggunakan siklus inisiasi-respons-evaluasi (Cazden, 1988) di mana guru mengajukan pertanyaan, siswa merespons, dan kemudian guru mengevaluasi jawabannya (Fisher, Frey, \& Rothenberg, 2008).

Pernyataan nomor 16 tentang "Hubungan antara manusia dengan Tuhan Yang Maha Esa merupakan hak pribadi yang paling hakiki”, direspon sangat setuju $96 \%$ oleh guru perempuan dan 93\% oleh guru laki-laki. Dalam Undang-undang Nomor 39 Tahun 1999 tentang Hak Asasi Manusia Pasal 1 disebutkan bahwa: "Hak Asasi Manusia adalah seperangkat hak yang melekat pada hakekat dan keberadaan manusia sebagai makhluk Tuhan Yang Maha Esa dan merupakan anugerah-Nya yang wajib dihormati, dijunjung tinggi, dan dilindungi oleh Negara, hukum, pemerintah, dan setiap orang demi kehormatan serta perlidungan harkat dan martabat manusia."

Pernyataan nomor 17 tentang "Setiap siswa tidak perlu terikat pada keluarga dan sekolah dalam menentukan agama yang dianutnya", 41\% guru perempuan menjawab setuju dan sangat setuju dan 30\% pada guru laki-laki, sehingga 70\% guru laki-laki menjawab tidak setuju dan sangat tidak setuju dan 59\% untuk guru perempuan. Sebagaimana termaktub dalam UUD 1945, "tiap-tiap penduduk diberikan kebebasan untuk memilih dan mempraktikkan kepercayaannya" dan "menjamin semuanya akan kebebasan untuk menyembah, menurut agama atau kepercayaannya". Namun demikian, dalam Islam orang tua kelak akan dimintai pertanggungjawabannya atas pendidikan pada anak-anaknya terutama pendidikan agama. Alquran Surat At Tahrim ayat 6 menyatakan: "Hai orangorang yang beriman, peliharalah dirimu dan keluargamu dari api neraka yang bahan bakarnya adalah manusia dan batu; penjaganya Malaikat-Malaikat yang kasar, keras, dan tidak mendurbakai Allah terhadap apa yang diperintabkan-Nya kepada mereka dan selalu mengerjakan apa yang diperintabkan." Ibnu Katsir dalam tafsirnya mengatakan bahwa maksud dari peliharalah dirimu dan keluargamu dari api neraka adalah didiklah dan ajarkan kepada keluarga kalian hal-hal yang membuat mereka taat kepada Allah. Dan melarang mereka dari berbuat maksiat kepadaNya. Serta memperbanyak zikir agar Allah menyelamatkan mereka dari api neraka. Maka dengan demikian memberikan pengetahuan agama terhadap anak merupakan tanggung jawab orang tua yang paling utama. Orang tua kelak akan 
Vol. 19, No. 1, 2020, Hal. 26-49

dimintai pertanggungjawaban akan anaknya di hari kiamat sebelum seorang anak ditanya pertanggungjawabannya atas orang tua mereka (Siregar, 2020).

Pernyataan nomor 18 tentang "Diperingatinya Hari Kartini atau Hari Ibu diharapkan dapat menggugah kesadaran guru tentang pentingnya kesetaraan dan keadilan gender”, 37\% guru perempuan sangat setuju dan 33\% untuk guru laki-laki. Sejalan dengan tujuan pendidikan multikultural untuk memfungsikan peranan sekolah dalam memandang keberadaan siswa yang beraneka ragam; untuk membantu siswa dalam membangun perlakuan yang positif terhadap perbedaan kultural, ras, etnik, kelompok keagamaan; memberikan ketahanan siswa dengan cara mengajar mereka dalam mengambil keputusan dan keterampilan sosialnya; untuk membantu peserta didik dalam membangun ketergantungan lintas budaya dan memberi gambaran positif kepada mereka mengenai perbedaan kelompok. Senada dengan pernyataan sebelumnya, pernyataan nomor 19 tentang "Perbedaan jenis kelamin dalam kelas tidak mengakibatkan perbedaan peran antara laki-laki dan perempuan", direspon sangat setuju sebanyak 48\% oleh guru perempuan dan 26\% guru laki-laki. Target pertama SDGs Indonesia pada tujuan pendidikan berkualitas adalah pada tahun 2030, menjamin bahwa semua anak perempuan dan laki-laki menyelesaikan pendidikan dasar dan menengah tanpa dipungut biaya, setara, dan berkualitas, yang mengarah pada capaian pembelajaran yang relevan dan efektif (sdgsindonesia.or.id).

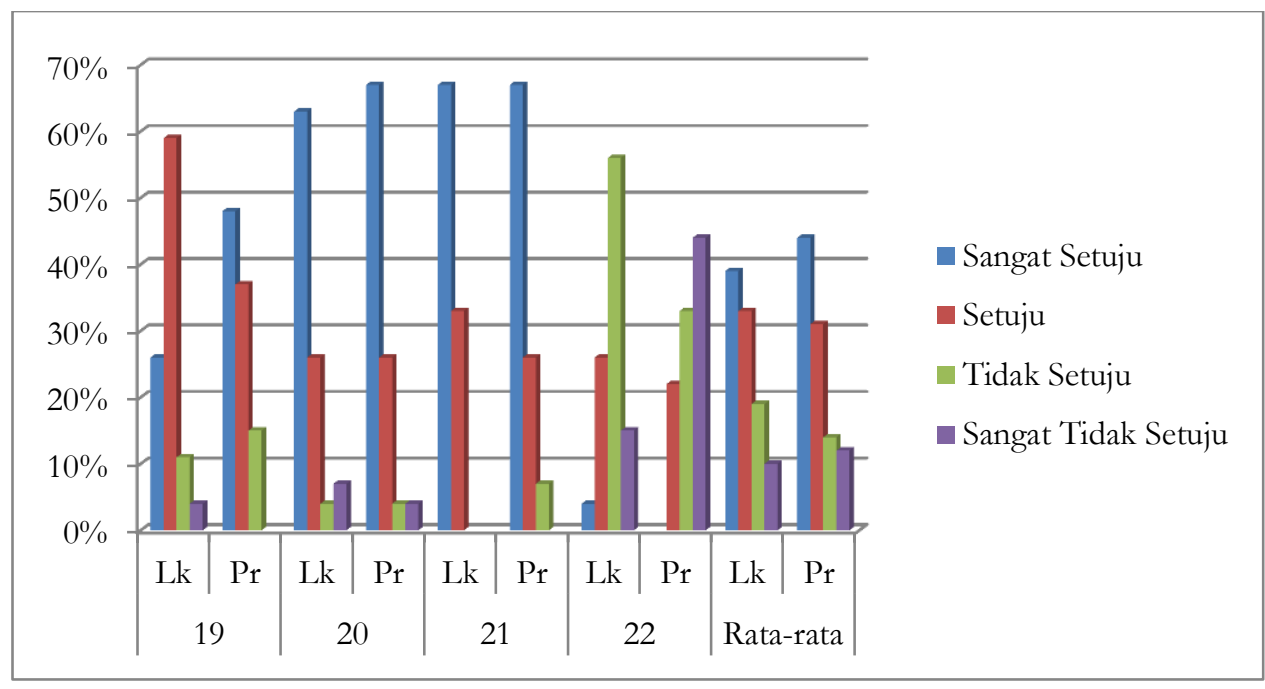

Gambar 5

Pemahaman Pluralistik Guru Laki-laki dan Guru Perempuan untuk Pernyataan 19-22 
Vol. 19, No. 1, 2020, Hal. 26-49

Selanjutnya pernyataan nomor 20 tentang "Memilih Kepala Sekolah tidak harus sesuai dengan daerah, agama, dan budaya mayoritas guru", terdapat 67\% guru perempuan menjawab sangat setuju dan 63\% guru laki-laki. Apakah sekolah yang dipimpin kepala sekolah laki-laki atau perempuan yang lebih berhasil mendapat bukti yang beragam dari penelitian sebelumnya. Hasil penelitian Elias (2013) di Bangladesh menunjukkan bahwa jenis kelamin kepala sekolah memiliki pengaruh yang signifikan terhadap keberhasilan akademik siswa. Hasil penelitian juga mengungkapkan bahwa siswa di sekolah dasar di bawah kepemimpinan kepala sekolah perempuan memiliki kinerja yang jauh lebih baik daripada yang dipimpin oleh kepala sekolah laki-laki, sedangkan siswa di sekolah menengah memperoleh nilai yang jauh lebih baik dalam ujian di bawah kepemimpinan kepala seklah laki-laki daripada siswa dipimpin oleh kepala sekolah perempuan.

Pernyataan nomor 21 tentang "Guru wajib memberikan sanksi tegas bagi siswa yang melakukan pelanggaran (mencontek) dalam kegiatan akademik di sekolah", guru laki-laki dan guru perempuan sama-sama merespon sangat setuju sebanyak 67\% sangat setuju. Perilaku mencontek dianggap sebagai tindakan tidak etis dan melanggar hukum. Ketika perilaku ini terjadi dalam bidang akademik, ini adalah situasi yang mengkhawatirkan dan merupakan masalah yang sangat serius yang membutuhkan perhatian besar. Jika perilaku ini tidak diredam, mungkin akan terus dipraktikkan di tempat kerja dan masalahnya akan berkembang menjadi jenis kecurangan, penipuan atau malpraktek lainnya. Analisis lebih lanjut mengenai mengapa siswa mencontek menunjukkan adanya ketakutan akan gagal $(64,2 \%)$, tidak cukup waktu $(55,8 \%)$ dan perlu mendapatkan nilai lebih baik (55\%) adalah pembenaran yang digunakan untuk melakukan perilaku mencontek (Hawani, dkk 2016).

Pernyataan nomor 22 tentang "Batasan umur siswa tidak perlu diberlakukan di sekolah agar tercipta keragaman umur", direspon sangat setuju oleh 30\% guru laki-laki dan 22\% guru perempuan. $44 \%$ guru perempuan merespon sangat tidak setuju sementara guru laki-laki 15\%. Hasil penelitian terkait pengaruh usia terhadap prestasi belajar menunjukkan temuan yang beragam. Hasil penelitian Momanyi, Too, \& Simiyu (2015) di Kenya menemukan bahwa usia siswa berpengaruh terhadap prestasi belajarnya. Siswa termuda mendapatkan skor lebih tinggi dibandingkan yang tertua. Namun, penelitian lain yang dilakukan oleh Rumberger (1995) menemukan bahwa siswa yang lebih tua memiliki skor yang lebih baik dibandingkan dengan siswa yang masuk sekolah pada umur lebih muda. Di Indonesia sendiri, aturan mengenai umur ditetapkan dalam Permendikbud no 44 tahun 2019 pada pasal 4-7. Dalam aturan tersebut dikemukakan bahwa syarat calon siswa mengikuti Penerimaan Peserta Didik Baru (PPDB) 2020 adalah berusia 7-12 tahun untuk Sekolah Dasar. Usia enam tahun diperuntukkan bagi calon siswa yang memiliki potensi kecerdasan dan atau bakat istimewa dan 
Vol. 19, No. 1, 2020, Hal. 26-49 kesiapan psikis. Pembuktian adanya potensi ini melalui rekomendasi dari psikolog professional. Menurut laman Sahabat Keluarga Kemdikbud RI aada 4 aspek mengapa umur minilam calon siswa adalah tujuh tahun. Secara fisik, anak berumur tujuh tahun dianggap paling siap karena gerakan motorik anak sudah lebih bagus, otot dan syarafnya juga sudah terbentuk. Secara psikologis, semakin tinggi umur siswa semakin meningkat kemampuan konsentrasinya. Secara kognitif, siswa diharapkan mampu membaca, menulis, dan berhitung sederhana. Terakhir dari aspek emosi, anak yang terlalu dini masuk sekolah dasar barangkali aspek akademisnya cukup matang, namun biasanya kematangan emosi dan kemandiriannya belum maksimal (Adit, 2019)

\section{Analisis Kuantitatif}

Berdasarkan analisis deskriptif yang telah dibahas sebelumnya terdapat perbedaan persepsi antara guru laki-laki dan perempuan. Untuk mengetahui perbedaan tersebut signifikan atau tidak akan dilanjutkan dengan menggunakan analisis kuantitatif. Tabel 2 menampilkan statistik deskriptif untuk ketiga nilai pendidikan multikultural yang diteliti.

Tabel 2. Statistik Deskriptif Nilai Demokrasi, Humanistik, dan Pluralistik antar Gender

\begin{tabular}{|l|c|c|c|c|c|c|}
\hline \multirow{2}{*}{$\begin{array}{l}\text { Jenis } \\
\text { Kelamin }\end{array}$} & \multicolumn{2}{|c|}{ Pendidikan Demokrasi } & \multicolumn{2}{c|}{ Pendidikan Humanistik } & \multicolumn{2}{c|}{ Pendidikan Pluralistik } \\
\cline { 2 - 7 } & Mean & Median & Mean & Median & Mean & Median \\
\hline Laki-laki & 34.0370 & 34.0000 & 17.4815 & 18.0000 & 24.0370 & 24.0000 \\
\hline Perempuan & 33.6296 & 34.0000 & 16.8148 & 17.0000 & 24.5185 & 25.0000 \\
\hline
\end{tabular}

Berdasarkan data pada Tabel 2 dapat dilihat bahwa terdapat perbedaan rata-rata (mean) antara laki-laki dan perempuan untuk setiap variabel. Perbedaan mean ini yang nantinya akan diuji apakah secara statistik signifikan atau tidak menggunakan Uji Beda Mann-Whitney. Tabel 3 berikutnya menampilkan hasil uji normalitas menggunakan Liliefors dan Shapiro Wilk.

Tabel 3. Uji Normalitas Data

\begin{tabular}{|c|c|c|c|c|c|c|c|}
\hline \multicolumn{8}{|c|}{ Tests of Normality } \\
\hline & \multirow{2}{*}{$\begin{array}{l}\text { Jenis } \\
\text { Kelamin }\end{array}$} & \multicolumn{3}{|c|}{ Kolmogorov-Smirnova } & \multicolumn{3}{|c|}{ Shapiro-Wilk } \\
\hline & & Statistic & $\mathrm{df}$ & Sig. & Statistic & $\mathrm{df}$ & Sig. \\
\hline \multirow{2}{*}{ Nilai Demokrasi } & Laki-laki & .202 & 27 & .006 & .862 & 27 & .002 \\
\hline & Perempuan & .246 & 27 & .000 & .820 & 27 & .000 \\
\hline \multirow{2}{*}{ Nilai Humanistik } & Laki-laki & .206 & 27 & .005 & .879 & 27 & .004 \\
\hline & Perempuan & .165 & 27 & .057 & .927 & 27 & .059 \\
\hline \multirow{2}{*}{ Nilai Pluralistik } & Laki-laki & .111 & 27 & $.200^{*}$ & .975 & 27 & .728 \\
\hline & Perempuan & .094 & 27 & $.200^{*}$ & .972 & 27 & .664 \\
\hline
\end{tabular}


Berdasarkan data pada Tabel 3 tersebut terlihat bahwa nilai pendidikan demokrasi memiliki angka signifikansi yang $<0.05$ baik untuk sampel laki-laki maupun perempuan. Hal ini mengindikasikan bahwa data tidak berdistribusi normal. Kondisi sebaliknya ditemukan untuk nilai signifikansi pendidikan pluralistik yang menunjukkan angka $>0.05$ yang berarti data berdistribusi normal. Sementara itu untuk pendidikan humanistic, sampel laki-laki menunjukkan data berdistribusi tidak normal, namun sampel perempuan menunjukkan data berdistribusi normal. Data akan membentuk distribusi normal apabila memiliki kesamaan dari jumlah data yang berada di atas dan di bawah mean. Selanjutnya Tabel 4 menampilkan hasil Uji Homogenitas menggunakan metode Levene's test. Uji ini dianjurkan untuk data yang tidak berdistribusi normal. Nilai Levene's test yang diperoleh untuk semua variabel ternyata $>0.05$ yang berarti asumsi homogenitas telah terpenuhi.

Tabel 4.Hasil Uji Homogenitas

\begin{tabular}{|l|l|r|r|r|r|}
\hline Pendidikan Multikultural & & $\begin{array}{c}\text { Levene } \\
\text { Statistic }\end{array}$ & df1 & df2 & Sig. \\
\hline Nilai Demokrasi & Based on Mean & 2.823 & 1 & 52 & .099 \\
\hline Nilai Humanistik & Based on Mean & .007 & 1 & 52 & .933 \\
\hline Nilai Pluralistik & Based on Mean & 1.716 & 1 & 52 & .196 \\
\hline
\end{tabular}

Setelah asumsi homogenitas terpenuhi, maka selanjutnya dilakukan uji beda Mann-Whitney untuk mengetahui apakah terdapat perbedaan persepsi antara guru laki-laki dan perempuan. Adapun hasil uji beda tersebut dapat dilihat pada Tabel 5.

Tabel 5. Hasil Uji Beda Mann-Whitney

\begin{tabular}{|l|r|r|r|}
\hline \multicolumn{4}{|c|}{ Test Statistics $^{\mathbf{a}}$} \\
\hline & $\begin{array}{c}\text { Pendidikan } \\
\text { Demokrasi }\end{array}$ & $\begin{array}{c}\text { Pendidikan } \\
\text { Humanistik }\end{array}$ & $\begin{array}{c}\text { Pendidikan } \\
\text { Pluralistik }\end{array}$ \\
\hline Mann-Whitney U & 356.500 & 287.000 & 324.000 \\
\hline Wilcoxon W & 734.500 & 665.000 & 702.000 \\
\hline Z & -.144 & -1.362 & -.705 \\
\hline Asymp. Sig. (2-tailed) & .886 & .173 & .481 \\
\hline a. Grouping Variable: Jenis Kelamin \\
\hline
\end{tabular}

Tabel 5 menunjukkan Mann-Whitney sebesar 356.500 untuk pendidikan demokrasi, 287.000 untuk pendidikan humanistik, dan 324.000 untuk pendidikan pluralistik. Sementara itu, nilai signifikansinya sebesar 0.886 untuk pendidikan demokrasi, 0.173 untuk pendidikan humanistik, dan 0.481 untuk pendidikan pluralistik. Semua nilai signifikansi untuk ketiga variabel yang diteliti $>0.05$ 
Vol. 19, No. 1, 2020, Hal. 26-49

maka disimpulkan bahwa tidak terdapat perbedaan yang signifikan antara persepsi guru laki-laki dan perempuan dalam menganut nilai-nilai pendidikan demokrasi, humanistik, dan pluralistik.

Alanay \& Aydin (2016) meneliti apakah terdapat perbedaan yang signifikan antara mahasiswa laki-laki dan perempuan terkait dengan pendidikan multikultural. Dalam penelitiannya mereka mengembangkan skala yang terbagi menjadi tiga kategori yaitu hasil pendidikan multikultural, pengaruh pendidikan universitas terhadap pendidikan multikultural, dan pendidikan dan keadilan. Hasil penelitian mereka menemukan bahwa tidak ada perbedaan yang signifikan antara mahasiswa laki-laki dan perempuan dalam hal hasil pendidikan multikultural dan pendidikan dan keadilan. Hanya pada pengaruh pendidikan universitas terhadap pendidikan multikultural terdapat perbedaan yang signifikan antara mahasiswa laki-laki dan perempuan.

Gorski (2000) sangat menekankan bahwa guru memiliki tanggung jawab ganda untuk terlibat dalam proses kritis dan berkelanjutan dalam mengevaluasi prasangka, bias, dan persepsi mereka yang mempengaruhi pengalaman belajar siswa. Untuk menjadi pendidik multikultural yang efektif dan instruktur yang efektif, seorang guru harus melanjutkan evaluasi dan transformasi diri. Nelson (2001) berpendapat bahwa memiliki sistem kepercayaan yang dipegang secara sosial dan menghargai perbedaan ras dan budaya adalah kunci untuk meningkatkan kesempatan yang sama bagi semua siswa (Sharma, 2005).

\section{KESIMPULAN}

1. Hasil penelitian ini menemukan bahwa terdapat perbedaan persepsi antara guru laki-laki dan perempuan terkait nilai-nilai pendidikan multikultural yaitu nilai demokrasi, humaistik, dan pluralistik. Namun demikian, secara statistik ditemukan bahwa perbedaan yang ada tidak signifikan sehingga dapat disimpulkan bahwa antara guru laki-laki dan guru perempuan memiliki persepsi yang hampir sama. Meneliti persepsi guru penting untuk dilakukan karena berdasarkan penelitian sebelumnya dinyatakan bahwa persepsi guru akan mempengaruhi harapan yang juga akan mempengaruhi bagaimana guru mendisain pembelajaran di kelas.

2. Secara rata-rata persepsi tentang nilai demokrasi baik guru laki-laki maupun perempuan berada pada kategori sangat setuju. Persepsi tentang nilai humanistik guru laki-laki dan guru perempuan juga berada pada rentang kategori sangat setuju. Namun persepsi tentang nilai pluralistik guru lakilaki dan guru perempuan berada pada rentag setuju. 
Vol. 19, No. 1, 2020, Hal. 26-49

3. Berdasarkan output statistik dalam uji Mann-Whitney diketahui bahwa nilai Asymp. Sig. (2-tailed) sebesar 0,886, 0,173, dan 0,481 lebih besar dari < nilai probabilitas 0,05. Oleh karena itu, sebagaimana dasar pengambilan keputusan uji Mann-Whitney di atas maka dapat disimpulkan bahwa tidak ada perbedaan persepsi tentang pelaksanaan pendidikan multikultural antara guru laki-laki dengan guru perempuan.

\section{SARAN}

1. Penelitian ini masih menggunakan indicator yang umum untuk pengukuran nilai-nilai pendidikan demokrasi, humanistic, dan pluralistic. Penelitian selanjutnya perlu mempertajam dan mendetilkan setiap indikator dari pendidikan multikultural dalam kajian penelitian yang lebih dalam.

2. Penelitian dapat dilanjutkan untuk melihat perbandingan persepsi siswa laki-laki dan siswa perempuan.

\section{DAFTAR PUSTAKA}

Adit, A. (2019) 4 Alasan Usia Anak Masuk SD Harus 7 Tahun, Berikut Penjelasannya, https://edukasi.kompas.com/read/2019/12/29/15090501/4-alasan-usia-anak-masuk-sdharus-7-tahun-berikut-penjelasannya?page $=$ all.

Alanay, H., \& Aydin, H. (2016) Multicultural Education: The Challenges and Attitudes of Undergraduate Students in Turkey, Education and Science, 41 (184), 169-191.

Alifah, P. (2018). Multicultural Education and Humanism Theory as an Effort to Improve the Social Sensibility of Primary School Students, Varia Pendidikan, 30 (1), 73-78.

Ameny-Dixon, G.M. (2004) Why Multicultural Education is More Important in Higher Education Now Than Ever: A Global Perspective. International Journal of Scholarly Academic Intellectual Diversity, 8(1), From http://www.nationalforum.com/dixon.h>

Blum, L. (2014) Three educational values for a multicultural society: Difference recognition, national cohesion and equality, Journal of Moral Education, 43 (3), 332-344, http://dx.doi.org/10.1080/03057240.2014.922057.

Colombo, M. (2012) Pluralism in Education and the multicultural reality of the schools.How do Italian teachers react?, Sociology of Education Research Network, SOE-RN 10 European. Sociological AssociationMid-term conference,Department of Sociology, Ghent University, Belgium, $13^{\text {th }}$ and $14^{\text {th }}$ of September 2012. 
Vol. 19, No. 1, 2020, Hal. 26-49

Diniaty, A. (2016) Perbedaan Penanganan Perilaku Siswa yang Mengganggu dalam Proses Pembelajaran Klasikal Sekolah Menengah oleh Guru Laki-laki dan Perempuan, Marwah: Jurnal Perempuan, Agama, dan Gender, 15 (2), 156-172.

Elias, M.S. (2013) Effect of Gender of the Head Teachers on the Academic Success of the School Students in Bangladesh, American Journal of Educational Research, 1 (6), 205-207

Fisher, D., Frey, N., \& Rothenberg, C. (2008) Content-Area Conversation: How to Plan Discussed-Based Lesson for Diverse language learner, http://www.ascd.org/publications /books/108035/chapters/Why-Talk-Is-Important-in-Classrooms.aspx

Gorski, P., (2000), The challenge of defining a single multicultural education, Multicultural education, http://www.mhhe.com/socinece/education/multi/define.html.

Hawani Wan Abdul Rahman N., Mat Dangi M.R., Jamaluddin S., Mustafa L.M., Yusop Y. (2016) Students' Cheating Behaviour in Higher Education System: Reconnoitring the Academic Integrity from the Accounting Students Perspectives. In: Abdullah M., Yahya W., Ramli N., Mohamed S., Ahmad B. (eds) Regional Conference on Science, Technology and Social Sciences (RCSTSS 2014). Springer, Singapore

Kariyawan, B. (2015) Meminimalisir Stereotipe antar Gender dengan Menggunakan Teknik Ungkap Tangkap Curahan Hati pada Materi Diferensiasi Sosial di SMA Cendana Pekanbaru, Marwab: Jurnal Perempuan, Agama, dan Gender, 14 (1), 38-56.

Kariyawan, B. (2016) Penggunaan Teknik Manajemen Konflik dalam Pembelajaran Sosiologi untuk Meredam Perilaku Berkonflik Siswa, Sosial Budaya, 13 (2), 152-161.

Marri, A.R. (2010) Multicultural Democracy: Toward a better democracy, Intercultural Education. 14 (3), 263-277, DOI: 10.1080/1467598032000117060.

Momanyi, J.M., Too, J., \& Simiyu, C. (2015) Effect of Students' Age on Academic Motivation and Academic Performance among High School Students in Kenya, Asian Journal of Education and eLearning, 3 (5), 2321-2454.

Mpofu, Elias, Thomas, Kenneth R. and Chan, Fong. (2004). "Social competence in Zimbabwean multicultural schools: Effects of ethnic and gender differences", International Journal of Psychology, 39 (3).

Nelson, T., (2001) Editor's Introduction: Advancing educational opportunities in a multicultural society, Teacher Education Quarterly, 26 (3), 147-156.

Oryan, S. \& Ravid, R. (2019) The experiences of pre-service teachers delivering a study unit on multiculturalism, racism and prejudice, Teaching and Teacher Education, 86, 1-10.

Peraturan Menteri Pendidikan dan Kebudayaan Republik Indonesia no 44 Tahun 2019 tentang Penerimaan Peserta Didik Baru. 
Vol. 19, No. 1, 2020, Hal. 26-49

Rockwell, A., Vidmar, C.M., Harvey, P., \& Greenwood, . (2019) Do Sociology Courses Make More Empathetic Students? A Mixed-Methods Study of Empathy Change in Undergraduates. Teaching Sociology, DOI: 10.1177/0092055X19860563.

Rong, X. L. (1996) Effect of Race and Gender on Teacher's Perception of the Social Behavior of Elementary Students, Urban Education, 31 (3), 261-290.

Shannon-Baker, P. (2018) A Multicultural Education Praxis: Integrating Past and Present, Living Theories, and Practice, International Journal of Multicultural Education, 20 (1), 48-66.

Sharma, S. (2015) Multicultural Education: Teachers' Perceptions and Preparation, Journal Of College Teaching And Learning . 2 (5), 53-64.

Siregar, R. (2020) 11 Kewajiban Orang Tua terhadap Anak Menurut Islam, https://kalam.sindonews.com/berita/1496497/69/11-kewajiban-orang-tua-terhadap-anakmenurut-islam

Tilaar, H.A.R. (2004). Paradigma Baru Pendidikan Nasional. Jakarta: Rineka Cipta.

UNESCO. (2019). Gender Report: Building Bridges for Gender Equality, The Global Education Monitoring Report Team, France.

Voronchenko, T. , Klimenko, T., \& Kostina, I. (2015) Learning to Live in a Global World: ProjectBased Learning in Multicultural Student Groups As a Pedagogy of Tolerance Strategy”, Procedia - Social and Behavioral Sciences, 191. 